\title{
EFFECTS OF A TYPICAL ANTIPSYCHOTIC AND THROMBOXANE A2 SYNTHASE INHIBITOR DRUG COMBINATION ON ALBUMIN AND TOTAL PROTEIN LEVEL WITH DIFFERENT DOSES IN RATS
}

\author{
MUHAMMAD IRFAN BASHIR* \\ Riphah Institute of Pharmaceutical Sciences, Riphah International University, Lahore, Pakistan. Email: mirfanbashir786@gmail.com \\ Received: 14 May 2019, Revised and Accepted: 10 June 2019
}

\section{ABSTRACT}

Objective: The objective of this study was to investigate the combined as well as individual effects of a typical antipsychotic and thromboxane A2 synthase inhibitor on albumin and total protein level with minimum and maximum dose comparison in rats.

Methods: This study consisted of 100 albino rats of 300 to $340 \mathrm{~g}$ from both gender, there were 10 groups, each contained 10 rats ( $\mathrm{n}=10$ ). Rats were treated with defined dose of zuclopenthixol (Zuclo) and ozagrel ( $\mathrm{Ozg}$ ) for 21 days ( 3 weeks). Blood samples were collected at $0,7^{\text {th }}, 14^{\text {th }}$, and $21^{\text {st }}$ days of study. Albumin and total protein level were examined from blood samples using standard laboratory procedure. Results are extracted by applying statistical analysis on data and comparing percentage variation from 0 -day value.

Results: A typical antipsychotic-treated group showed gradually significant increase in albumin and total protein level, TXA2 synthase inhibitortreated group also showed significant gradually increase in albumin and total protein level in combination groups, they showed highly significant increase $\mathrm{p}<0.001$ in both parameter with maximum dose.

Conclusion: Combination treatment with zuclopenthixol (Zuclo) and ozagrel (Ozg) can cause large increase on albumin and total protein level with maximum dose as compare to individual drug treatment.

Keywords: Atypical antipsychotic, Thromboxane A2 synthase, Zuclopenthixol, Albumin, Total protein level, Ozagrel.

(C) 2019 The Authors. Published by Innovare Academic Sciences Pvt Ltd. This is an open access article under the CC BY license (http://creativecommons. org/licenses/by/4. 0/) DOI: http://dx.doi.org/10.22159/ajpcr.2019.v12i7.34122

\section{INTRODUCTION}

As per the World Health Organization (WHO) report, stroke and other cerebrovascular maladies and its codreary ailment one of among them are mental confusions. Mental illness and cerebrovascular illness incorporate diseases, for example, tension, psychosis, posttraumatic stress issue (PTSD), and post-stroke depression (PSD) in such a condition medications for psychosis are included with blend of stroke prescription (antithrombotic drugs) to treat the post-stroke depression [1]. Atypical antipsychotic drugs are valuable in diminishing animosity psychosis yet are related with genuine cerebrovascular occasions and extrapyramidal manifestations. The occasions affirm that atypical antipsychotic medications ought to be observed routinely to treat psychosis [2].

Atypical antipsychotic tranquilizes clinically help patients by temporarily involving D2 receptors and afterward quickly separating to permit typical dopamine neurotransmission [3]. Atypical antipsychotic tranquilizes normally cause asymptomatic increment in the liver parameters and serum bilirubin levels. Anyway, they once in a while may incite a genuine hepatic harmfulness. Analysts recommend that getting gauge liver tests before atypical antipsychotic treatment and observing normally explicitly in patients with hazard factors for liver harm amid therapy [4]. Developing proof as of now proposes that in any event two of the atypical antipsychotics, clozapine and zuclopenthixol [5]. Antipsychotic drug is a tranquilizing psychiatric medication primarily used for the treatment of psychosis, schizophrenia, and mental retardations such as bipolar disorder, delusions, paranoid disorder, and depression [6].

Sodium ozagrel, a specific thromboxane A2 (TXA2) synthetase inhibitor, has been utilized for the treatment of different kinds of intense ischemic stroke, aside from cardioembolic stroke [7]. The
TXA2 synthase inhibitor, ozagrel, drastically reduces liver damage in mice and proposes that it is a promising restorative possibility for the treatment of actuated liver damage [8]. One promising exploration course is the investigation of the TXA2 receptor hub. Analyst recommends that deliberate works around there are making new and promising open doors in the treatment of patients with cardiovascular diseases [9]. Albumin is the most inexhaustible plasmatic protein. It is just created by the liver and the full degree of its metabolic capacities is not known in detail [10]. The significance of albumin organization in the basic consideration setting stays disputable. We realize that albumin has various significant physiological impacts and numerous possibly gainful impacts in basic sickness. Abatement albumin showed insufficiency of liver and increment demonstrates some damage, harming, and infectious states [11]. Albumin is in among the rundown of those proteins which made in the liver. Living life forms need such proteins for security against diseases and to do different capacities. Lower levels than a standard dimension of albumin and all-out protein will indicate liver damage [12]. Albumin provides a terminus as that the drugs will be available beyond their soluble quantities in the plasma [13].

The total protein test estimates the aggregate sum of two classes of proteins found in the liquid segment of your blood. These are albumin and globulin [14]. Proteins are significant pieces everything being equal and tissues. Albumin keeps liquid from spilling out of veins. A scientist has prior revealed a stamped height in the serum dimensions of basic phosphatase (ALP), glutamic-oxaloacetic transaminase (SGOT), and glutamic-pyruvic transaminase (SGPT) in rabbits [15]. An antiplatelet drug (ozagrel sodium) which has TXA2 synthase inhibitor activity is used to treat the brain ischemia and zuclopenthixol belongs to atypical antipsychotic class of antipsychotic drugs, this drug is used to treat the psychotic issues and depression disorders [16]. Combined treatment with both drugs 
takes place in the patients who have thrombosis and psychotic illness comorbidity or in depression caused by stroke (post-stroke depression). Combination study for those drugs which have not already been examined during combined effect is very important on different parameters. In this study, we had observed individual as well as combined effects of these two drugs on albumin and total protein level. This study indicated combined side effect of these drugs on liver protein which will be led liver injury. Drug-drug interaction of these two drugs regarding albumin and total protein level is not yet studied which is described in this article novelty.

\section{MATERIALS AND METHODS}

\section{Ethical statement}

All protocols of this experiment and animal handlings procedure were done accordingly EEC council which were approved by the Ethical Committee of Riphah International University, through an authorized number of REC/RIPS-LHR/2017/005 ruled under the regulation of Institute of Laboratory Animal Resources, Commission on Life Sciences University, National Research Council (1996), which were for minimizing the animal suffering.

\section{Chemical and drugs}

Zuclopenthixol (Zuclo) injection (atypical antipsychotic drug by Clopixol inj. Lundbrook Pharma), Ozagrel (Ozg) injection (Ozac by Graton Pharma) as TXA2 synthase inhibitor, sodium chloride (Merck), vegetable thin oil, and isoflurane (Akhai Pharmaceuticals) were of research grade, purchased from local market.

\section{Experimental animals}

This study consisted of 100 albino rats of 300 to $340 \mathrm{~g}$ from both gender, there were 10 groups, each contained 10 rats $(n=10)$. Seven days before start treatment, they were housed at $22 \pm 2^{\circ} \mathrm{C}$ temperature, $45-55 \%$ humidity, and $12 \mathrm{~h}$ day and light cycle in animal house of Riphah Institute of Pharmaceutical Sciences [17]. They had free access to food and water. Duration of treatment was 3 weeks [18]. Animals were divided into 10 groups $(\mathrm{n}=10)$.

\section{Experimental design}

Zuclo indicates (Zuclopenthixol) and Ozg indicates (Ozagrel)

Group I: Control thin oil (vehicle) treated group through I/m as base of Clopixol injection

Group II: Control normal saline (vehicle) treated group through I/v route. Group III: Zuclo-treated group by $7.14 \mathrm{mg} / \mathrm{Kg}$

Group IV: Ozg-treated group by $11.42 \mathrm{mg} / \mathrm{Kg}$.

Group V: Zuclo-treated group by $28.57 \mathrm{mg} / \mathrm{Kg}$ dose

Group VI: Ozg-treated group by $22.85 \mathrm{mg} / \mathrm{Kg}$ dose

Group VII: Zuclo+Ozg treated group by $7.14 \mathrm{mg} / \mathrm{Kg}$ (Zuclo) $+11.42 \mathrm{mg} / \mathrm{Kg}(\mathrm{Ozg})$

Group VII: Zuclo+Ozg treated group by $28.57 \mathrm{mg} / \mathrm{Kg}$ (Zuclo) $+22.85 \mathrm{mg} / \mathrm{Kg}(\mathrm{Ozg})$

Group IX: Zuclo+Ozg treated group by $28.57 \mathrm{mg} / \mathrm{Kg}$ (Zuclo) $+11.42 \mathrm{mg} / \mathrm{Kg}(\mathrm{Ozg})$

GroupX:Zuclo+Ozg treatedgroupby $7.14 \mathrm{mg} / \mathrm{Kg}$ (Zuclo) $+22.85 \mathrm{mg} / \mathrm{Kg}(\mathrm{Ozg})$.

Route of (Zuclo) was I/m route of drug administration and route of Ozg (Ozagrel) was I/p route of drug administration.

\section{Blood collection}

Rats were anesthetized using the isoflurane [19]. Blood samples were collected at $0,7^{\text {th }}, 14^{\text {th }}$, and $21^{\text {st }}$ days of the study. About $1 \mathrm{~mL}$ sample was withdrawn at each sampling day. Serum and plasma were obtained from sample.

\section{Blood analysis}

Albumin and total protein level were examined from blood samples using chemistry analyzer with standard laboratory procedures.

\section{Statistical analysis}

With respect to 0 -day value of every group, percentage increase or decrease and mean with SD for each parameter were calculated.
Inferential statistics applied by the use of two-way ANOVA. Graphs were made using GraphPad Prism version 5.0. Pattern of significant was as ${ }^{*} p<0.05$, moderately significant was represented as ${ }^{* *} \mathrm{p}<0.01$, and highly significant was represented as ${ }^{* * *} \mathrm{p}<0.001$.

\section{RESULTS}

Effect of atypical antipsychotic (zuclopenthixol) and TXA2 synthase inhibitor (ozagrel) per se and in combination on albumin in rats

Table 1 shows that normal oil-treated group showed no significance variations during treatment and normal saline-treated group also did not show any significance change on albumin level within total duration of treatment as compare to 0 -day values. Table 1 also presents that Zuclo (min) treated group showed gradually significant increase in albumin level with $\mathrm{p}<0.01$ at the $21^{\text {st }}$ day, Ozg (min) treated group showed non-significant gradually increase in albumin level, Zuclo (max) treated group showed significant increase with $\mathrm{p}<0.001$ at the $21^{\text {st }}$ day, Ozg (max) treated group showed increase in albumin level gradually with $\mathrm{p}<0.001$ at the $21^{\text {st }}$ day, and Zuclo (min)+Ozg (min) treated group showed gradually increase in albumin level with $p<0.001$ at the $21^{\text {st }}$ day, whereas Zuclo(max)+Ozg(max) combination group showed gradually significant increase in albumin level with $\mathrm{p}<0.001$ at the $21^{\text {st }}$ day, Zuclo(max $)+O z g(\min )$ combination showed gradually increase in albumin level by $\mathrm{p}<0.001$ at the $21^{\text {st }}$ day and Zuclo(min)+Ozg(max) showed increase in albumin level gradually by $p<0.001$ at the $21^{\text {st }}$ day in comparison to 0 -day values.

Effect of atypical antipsychotic (Zuclopenthixol) and TXA2 synthase inhibitor (ozagrel) per se and in combination on total protein level in rats

Figure 1 shows graphical expression of percentage variation in total protein as compare 0 -day values. Normal oil-treated group showed no significance variations during treatment and normal saline-treated group also did not show any significance change on total protein level within total duration of treatment as compare to 0 -day values. Figure 1 also presents that Zuclo ( $\mathrm{min}$ ) treated group showed gradually significant increase in total protein level with $\mathrm{p}<0.001$ at the $21^{\text {st }}$ day, Ozg (min) treated group showed non-significant gradually increase in total protein level, Zuclo (max) treated group showed significant increase with $p<0.001$ at the $21^{\text {st }}$ day, Ozg ( $\max$ ) treated group showed increase in total protein level gradually with $\mathrm{p}<0.001$ at the $21^{\text {st }}$ day, and Zuclo $(\mathrm{min})+\mathrm{Ozg}(\mathrm{min})$ treated group showed gradually increase in total protein level with $\mathrm{p}<0.001$ at the $21^{\text {st }}$ day, whereas Zuclo (max)+0zg (max) combination group showed gradually significant increase in total protein level with $\mathrm{p}<0.001$ at the $21^{\text {st }}$ day, Zuclo (max)+Ozg ( $\mathrm{min}$ ) combination showed gradually increase in total protein level by $\mathrm{p}<0.001$ at the $21^{\text {st }}$ day, and Zuclo (min)+0zg (max) showed increase in total protein level gradually by $\mathrm{p}<0.001$ at the $21^{\text {st }}$ day in comparison to 0 -day values.

\section{DISCUSSION}

Atypical antipsychotic drug (zuclopenthixol) significantly increased proteins tests value (total protein and albumin levels) with both minimum and maximum doses in this study which was supported by another study, in which antipsychotic drugs have been associated with high fatal hepatic injury [20]. Another study on this drug showed large increase of liver function tests values and researcher suggested that this is due to its activity on human liver cytochrome P-450 (CYP) inhibition of CYP2D6 [21].

TXA2 synthase inhibitor $(\mathrm{Ozg})$ treated groups showed also a significant increase in the albumin and total protein level with both doses. A previous study showed that the TXA2 synthase inhibitor, ozagrel, dramatically alleviates liver injury in mice and raise the protein levels in blood. Researcher suggested a mechanism that ozagrel had little impact on CYP2E1 activity involving the NAPQI (N-acetyl-pbenzoquinone imine) production. In addition, ozagrel significantly attenuated cell injury induced by NAPQI ( $\mathrm{N}$-acetyl-p-benzoquinone 
Table 1: Effect of atypical antipsychotic (zuclopenthixol) and thromboxane A2 synthase inhibitor (ozagrel) per se and in combination on albumin level

\begin{tabular}{|c|c|c|c|c|}
\hline Treated groups & 0 day & $7^{\text {th }}$ day & $14^{\text {th }}$ day & $21^{\text {st }}$ day \\
\hline Normal thin oil & $3.5 \pm 0.2$ & $3.5 \pm 0.1$ & $3.5 \pm 0.2$ & $3.5 \pm 0.2$ \\
\hline N.S (normal saline) & $3.3 \pm 0.1$ & $3.3 \pm 0.1$ & $3.4 \pm 0.1$ & $3.3 \pm 0.1$ \\
\hline \multirow[t]{2}{*}{ Zuclo (Min) } & $4.32 \pm 0.3$ & $4.46 \pm 0.3$ & $4.42 \pm 0.2$ & $4.46 \pm 0.3$ \\
\hline & & $\uparrow(2.8)^{*}$ & $\uparrow(2.3)$ & $\uparrow(3.2)^{* *}$ \\
\hline \multirow[t]{2}{*}{ Ozg (Min) } & $4.5 \pm 0.2$ & $4.5 \pm 0.2$ & $4.6 \pm 0.2$ & $4.6 \pm 0.2$ \\
\hline & & $\uparrow(1.3)$ & $\uparrow(1.8)$ & $\uparrow(1.8)$ \\
\hline Zuclo (Max) & $3.2 \pm 0.11$ & $3.3 \pm 0.1$ & $3.4 \pm 0.1$ & $3.5 \pm 0.1$ \\
\hline \multirow[t]{2}{*}{ Ozg (Max) } & $4.1 \pm 0.1$ & $4.2 \pm 0.1$ & $4.3 \pm 0.1$ & $4.5 \pm 0.1$ \\
\hline & & $\uparrow(0.9)$ & $\uparrow(2.9)^{* *}$ & $\uparrow(7.7)^{* * *}$ \\
\hline \multirow[t]{2}{*}{ Zuclo (Min)+Ozg (Min) } & $3.4 \pm 0.1$ & $3.6 \pm 0.1$ & $3.7 \pm 0.1$ & $3.88 \pm 0.1$ \\
\hline & & $\uparrow(4.6)^{* * *}$ & $\uparrow(6.4)^{* * *}$ & $\uparrow(12.2)^{* * *}$ \\
\hline \multirow[t]{2}{*}{ Zuclo (Max)+Ozg (Max) } & $4.1 \pm 0.1$ & $4.3 \pm 0.1$ & $4.6 \pm 0.2$ & $4.8 \pm 0.1$ \\
\hline & & $\uparrow(4.2)^{* * *}$ & $\uparrow(10.9)^{* * *}$ & $\uparrow(14.4)^{* * *}$ \\
\hline \multirow[t]{2}{*}{ Zuclo (Max)+Oz (Min) } & $3.6 \pm 0.1$ & $3.7 \pm 0.2$ & $3.9 \pm 0.2$ & $4.1 \pm 0.2$ \\
\hline & & $\uparrow(2.1)$ & $\uparrow(7.6)^{* * *}$ & $\uparrow(12)^{* * *}$ \\
\hline Zuc (Min)+Oza (Max) & & $\uparrow(4.6)^{* * *}$ & $\uparrow(7.2)^{* * *}$ & $\uparrow(13.2)^{* * *}$ \\
\hline
\end{tabular}

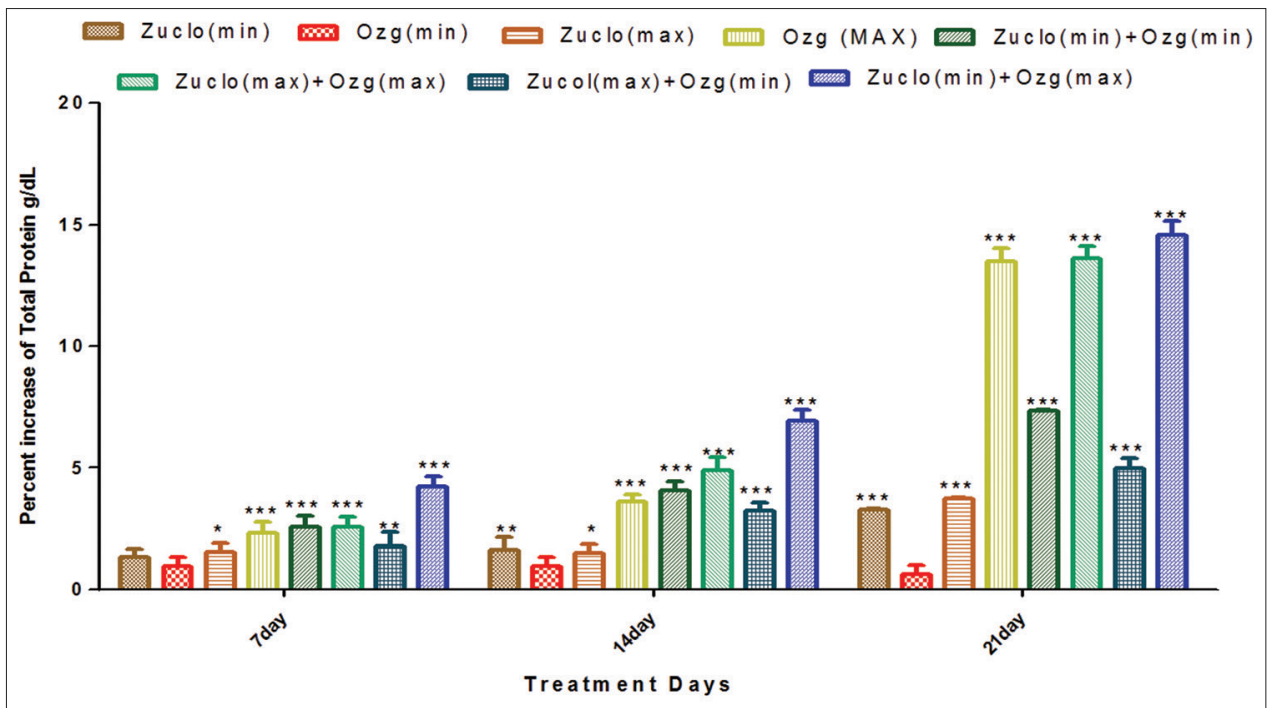

Fig 1: Effect of atypical antipsychotic (Zuclopenthixol) and TXA2 synthase inhibitor (ozagrel) per se and in combination on total protein level in rats. ${ }^{*} \mathbf{p}<0.05,{ }^{* *} \mathbf{p}<0.01$, and ${ }^{* * *} \mathbf{p}<0.001$ as compared to their 0 -day values

imine) [8]. High protein levels in blood indicated a serious infection and liver injury [22]. In our present study, these effects are explained with different doses of ozagrel which are not observed before, in which we have showed that with minimum dose. In this study, we also impart a light on protein binding factor of drug increase level of albumin and other protein can increase the half-life of other drugs which are used with these drugs as an adjunct therapy to treat the comorbid diseases. This statement is supported by another researcher work which stated that the liver is the major site of metabolism, the effect of hepatic dysfunction on drug disposition is very important to observe large protein release from of protein can increase the protein binding of drugs which affects the half-life of its own and other drugs used in combined therapy. Hepatic dysfunction can take part in drug disposition abundantly [23].

It is hypothesized that these drugs can raise both protein levels due to liver injury caused by their combined activities on liver enzymes with maximum doses. Minimum dose in combination showed low increase as compare to maximum dose combination.

\section{CONCLUSION}

It is concluded that combination therapy with atypical antipsychotic and TXA2 synthase inhibitor drugs with maximum dose enhanced the albumin and total protein level in comparison to monotherapy. It is recommended that combination therapy with maximum dose can be acted as enhancer of these proteins as compare to minimum dose combination therapy. This study concluded that monitoring of liver functions is necessary during treatment with these drugs, alone and in combination with maximum dose specifically, an increased level of proteins in blood can alter the protein binding of another drug in polypharmacy as adjunct therapy with these drugs.

\section{CONFLICTS OF INTEREST}

The author declares that no conflicts of interest in this article.

\section{AUTHORS' CONTRIBUTION}

Central idea and experimental design to finalization of draft all done by Muhammad Irfan Bashir.

\section{ACKNOWLEDGMENT}

I thank all who support me and provide technical assistance. 


\section{REFERENCES}

1. Capaldi VF $2^{\text {nd }}$, Wynn GH. Emerging strategies in the treatment of poststroke depression and psychiatric distress in patients. Psychol Res Behav Manag 2010;3:109-18.

2. Ballard CG, Waite J, Birks J. Atypical antipsychotics for aggression and psychosis in Alzheimer's disease. Cochrane Database of Syst Rev 2006; 1:CD003476.

3. Seeman P. Atypical antipsychotics: Mechanism of action. Focus 2004; 47:27-58.

4. Atasoy N, Erdogan A, Yalug I, Ozturk U, Konuk N, Atik L, et al. A review of liver function tests during treatment with atypical antipsychotic drugs: A chart review study. Prog Neuropsychopharmacol Biol Psychiatry 2007;31:1255-60.

5. Liebzeit KA, Markowitz JS, Caley CF. New onset diabetes and atypical antipsychotics. Euro Neuropsychopharmacol 2001;11:25-32.

6. Pahari N, Tripathi SK, Maity T, Gupta BK, Bagchi C, Mondal DK. Evaluation and analysis of adverse drug reactions of second generation antipsychotics in a psychiatry out-patient department. Int J Pharm Pharm Sci 2012;4:158-62.

7. Takabatake Y, Uno E, Wakamatsu K, Yamazaki N, Hashimoto N, Tsuchiya $\mathrm{Y}$, et al. The clinical effect of combination therapy with edaravone and sodium ozagrel for acute cerebral infarction. No To Shinkei 2003;55:589-93.

8. Tomishima $\mathrm{Y}$, Ishitsuka $\mathrm{Y}$, Matsunaga N, Nagatome M, Furusho H, Irikura $\mathrm{M}$, et al. Ozagrel hydrochloride, a selective thromboxane $\mathrm{A}_{2}$ synthase inhibitor, alleviates liver injury induced by acetaminophen overdose in mice. BMC Gastroenterol 2013;13:21.

9. Mesitskaya DF, Syrkin AL, Aksenova MG, Zhang Y, Zamyatnin J, Andrey A, et al. Thromboxane a synthase: A new target for the treatment of cardiovascular diseases. Cardiovasc Hematol Agents Med Chem 2018;16:81-7.

10. Cabrerizo S, Cuadras D, Gomez-Busto F, Artaza-Artabe I, Marín-Ciancas F, Malafarina V, et al. Serum albumin and health in older people: Review and meta analysis. Maturitas 2015;81:17-27.

11. Vincent JL. Relevance of albumin in modern critical care medicine.
Best Pract Res Clin Anaesthesiol 2009;23:183-91.

12. Yap CY, Aw TC. Liver function tests (LFts). Proc Singapore Healthc 2010;19:80-2

13. Somaji L, Rapolu R. Binding studies of valganciclovir to human serum albumin by multispectroscopic techniques. Int J Pharm Pharm Sci 2018;10:87-92.

14. Mohamed NY. Evaluation of Plasma Levels of Total Protein and Albumin in Sudanese Children with Malnutrition in Khartoum State. Khartoum: Sudan University of Science and Technology; 2017.

15. Orhue N, Nwanze E, Akafor A. Serum total protein, albumin and globulin levels in Trypanosoma brucei infected rabbits: Effect of orally administered Scoparia dulcis. Afr J Biotechnol 2005;4:1152-5.

16. Bashir MI, Saleem U, Anwer F, Ahmad B. Effects of thioxanthene containing anti-psychotic and anti-platelet drug combination on mean platelet volume and platelet distribution width in rats. J Pharm Res Int 2019;27:1-7

17. Hira S, Saleem U, Anwar F, Ahmad B. Antioxidants attenuate isolationand L-DOPA-induced aggression in mice. Front Pharmacol 2017:8:945.

18. Khedr EM, Al Fawal B, Abdelwarith AM, Saber M, Tony AAH, El-Bassiony A, et al. Changes in recruitment of motor cortex excitation and inhibition in patients with drug-induced tardive syndromes. Neurophysiol Clin 2019;49:33-40.

19. Tsukamoto A, Uchida $\mathrm{K}$, Maesato S, Sato R, Kanai E, Inomata T, et al. Combining isoflurane anesthesia with midazolam and butorphanol in rats. Exp Anim 2016;65:223-30.

20. Marwick KF, Taylor M, Walker SW. Antipsychotics and abnormal liver function tests: Systematic review. Clin Neuropharmacol 2012;35:244-53.

21. Shin JG, Soukhova N, Flockhart DA. Effect of antipsychotic drugs on human liver cytochrome P-450 (CYP) isoforms in vitro: Preferential inhibition of CYP2D6. Drug Metab Dispos 1999;27:1078-84.

22. Mahmoud MR, El-Abhar HS, Saleh S. The effect of Nigella sativa oil against the liver damage induced by Schistosoma mansoni infection in mice. J Ethnopharmacol 2002;79:1-11.

23. Blaschke TF. Protein binding and kinetics of drugs in liver diseases. Clin Pharmacokinet 1977;2:32-44. 